LSP International Journal, Vol. 6, Issue 2, 2019, 1-21

(C) Universiti Teknologi Malaysia

E-ISSN 2601-002X

DOI: https://doi.org/10.11113/lspi.v6n2.86

\title{
Genre-based Analysis of Travel Guides: A Study on Malaysia, Thailand and the Philippines
}

\author{
Bashar Abdulkareem Alali \& Afiza Mohamad Ali \\ Kulliyyah of Languages and Management, International Islamic University Malaysia \\ Afida Mohamad Ali \\ Faculty of Modern Languages and Communication, Universiti Putra Malaysia \\ Submitted: 26/05/2019. Revised edition: 20/09/2019. Accepted: 25/09/2019. Published online: 05/12/2019
}

\begin{abstract}
The language of travel guides can help highlight the importance of modelling the mind of the readers and changing them from readers to actual clients. This paper reports a genre- based analysis study of a move-structure of online tourist travel guides of three Asian countries: Malaysia, Thailand and the Philippines. Kathpalia's nine-move structure (1992) for advertising is adopted as a framework to analyse the selected travel guides using Atlas ti (a qualitative data analysis software). Data selection is based on the latest edition of Asian online travel guides. The main purposes of this study are to analyze the move structures, their strategies and communicative purposes, identify the prevalent move(s) in the selected travel guides, as well as to find out whether the selected travel guides have the same move structures. The findings of this study show that the travel guides have different quantity of moves. The prevalent moves in these three travel guides were also identified. Results highlight the diversity and strategies of moves in the online travel guides which are related to the nature of the country, perception and aims of the writer to promote or persuade readers. A brief discussion on these categories, and teaching implications follow these findings.
\end{abstract}

Keywords: Genre analysis, move-structure analysis, travel guides, English for Specific Purposes

\section{INTRODUCTION}

The tourism industry has progressed rapidly in the recent years. The Travel \& Tourism Economic Impact 2018 report forecasted a robust growth of the travel \& tourism sector as millions of people travel to see the wonders of the world (https://www.wttc.org/-/media/files/reports/economic-impactresearch/countries-2018/malaysia2018.pdf). Working as the information carrier to publicize, advertise and market tourist destinations, the analysis of travel guides in applied linguistics field should be given attention. Dann (1996) stated that without discourse of marketing and publicity in such advertisement, there would be very little tourism promotion.

*Correspondence to: Afiza Mohamad Ali (email: drfiza@iium.edu.my) 
The importance of discourse in promoting tourism shows the significant role of language for specific purposes. Hence, English for Specific Purposes (ESP), which emerged in the 1960s to fulfil learners' and industries' linguistic need, focuses on the learner and the special language used in special professional cases.

English language as a language of trade and advertisement is especially significant for the tourism industry. Those in the tourism industry would need the competence in all four-language skills to be able to meet the linguistic needs of the industry (Sirikhan \& Prapphal, 2011; Bobanovic, 2011; Iborra and Garrido, 2001). For instance, Henry and Roseberry (2001) confirm that the development of effective promotional materials by content writers are sought after, while promotional texts like handbooks, advertisements, leaflets or travel guides should be effective and persuasive enough to fulfil the aims of tourism industries (Salehi and Farahbakhsh, 2014; Dann, 1996) to advertise accurate and important information, by influencing and arousing interest as well as creating a favourable image to stimulate tourists' desire (Cheng \& Suen, 2014). Hence, writing with this communicative purpose in mind in a second language may be an uphill task for second language learners (Jun, 2008). Nonnative speakers of English require not only an excellent knowledge of English such as grammar and vocabulary (Huyen \& Nga, 2003) but also a special training on how to write persuasively and effectively for professional or specific purposes like tourism (Amerrudin \& Farideh, 2015).

The present study on travel guide discourse is conducted based on English for Special Purpose (ESP) School's theory from the viewpoint of genre analysis to examine the rhetorical moves and strategies used to promote the tourist destination. According to Filatova (2012; cited in Holovach, 2011 , p.12) "the travel guide as an essential source of information about natural, economic, cultural and household peculiarities of the country enables communication between the representatives of various countries in the cultural space." This definition indicates extra features of the travel guide as reference for economic, historical, cultural and natural information about the attraction of the entire country in a one document. Hence, the present study intends to investigate thereby making proposals for the improvement on travel guide writing as well as extending the literature on move structure analysis of promotional genre. By this means, insight of overall strategies, and techniques in the useful writing process for a country's travel guide could be established. The study aims to answer the research questions below, by analysing the travel guides of three countries, namely, Malaysia (2015), Thailand (2007) and the Philippines (2014):

1. What are the move structures, strategies and communicative purposes in the selected travel guides?

2. What are the prevalent move/s in the selected travel guides?

3. To what extent are the move patterns different in the three travel guides? 


\section{LITERATURE REVIEW}

\section{Genre Analysis and ESP}

Genre analysis relates to an ESP approach to analyse text from a pedagogic perspective of language usage in professional setting (Dudley-Evans, 1994). The method focuses on presentation, order and style of content, as well as various rhetorical factors that affect how readers regard meaning presented in the text. Swales (1990) pioneered his Create-A- Research-Space (CARS) model to analyse the macrostructure of introductions of research articles, and identified particular moves and steps that serve a specific intent of the general purposes of the genre. Bhatia (1993) extended this model by analysing two types of business letters called 'promotional genre', and found the same generic move structure that serve similar communicative purposes to persuade customers He replaced steps with the term "strategy" to explain the specific realization or construction of the move.

\section{Studies on Promotional Genre}

A promotional genre defined by Bhatia $(1993$, p. 96) is characterized by its communicative purposes as follows:

1. To persuade the customers to take an action

2. To capture the attention of potential customers

3. To offer an appraisal such as the interests and needs of the potential customers

4. To offer short and effective letters for business persons

5. To encourage further communication

This parallels with the fundamental nature of advertising language that uses words and images to persuade and convince clients to commit to the product (Berger, 2004; Henry and Roseberry, 2001). A travel guide thus presents itself as a sub-genre of promotional tourism genre by providing readers with attraction information to travel.

Many genre analysis studies on tourism promotional genre have been done especially in advertising materials like tourist texts (Henry and Roseberry, 1996), tourist brochures (Osman, 2013; Öztürk, 2014; Luo and Huang, 2015) and leaflets (Iborra and Garrido, 2001). These studies have found different structural components to such texts which have implications to the knowledge and teaching of such genre. Öztürk (2014) analyzed Turkish tourism brochure based on Bhatia's (2004) framework and found recurring moves and linguistic features such as the usage of self-references, verbs, models, tenses, adjectives and pictures, that are used for persuasive communicative purposes though the study was limited to only one brochure. On the other hand, in an early study by Henry and Roseberry (1996) on English tourist texts, three obligatory moves were detected, namely 'location', 'facilities/ activities', and 'description'.

In constrast, Huang (2015) analysed 30 Brief Tourist Information (BTI) texts on tourism destination websites and found that 'the Establishing Credentials' move presents a vital role in introducing and promoting the destination and is considered as the obligatory move in BTI. Iborra 
and Garrido (2001) studied the moves and linguistic features of 12 authentic English travel leaflets while Kathpalia (1992) investigated three promotional texts based on Swales' move model (1990). Her sample consisted of three printed advertisements (blurbs, printed advertisements, and promotional letters) collected from various sources. A nine-move structure as a result of her generic analysis was developed (ibid, p.177):

Move 1. Headlines

Move 2. Targeting the Market

Move 3. Justifying the Product/Service Move 4. Appraising the Product/Service Move 5. Establishing Credentials

Move 6. Endorsements/Testimonials Move 7. Offering Incentives

Move 8. Using Pressure Tactic Move 9. Urging Action

Other studies have also adopted the framework to study car advertisements (How, 1995), residential property advertisements (Choo, 1998), in-flight magazine advertisements (Zanariah, 2003). These studies reveal that the nature of promotional genre moves akin to Kathpalia's can take the form of advertising or selling of products, be it tourism destinations, cars or properties using different text forms at different level of organization like the macro-level features of textual organization, and micro-level features at the sentence level. While these studies have looked at common types or promotional genre, the generic structure of online travel guides has yet to be explored.

\section{METHOD}

The present study adopts a qualitative research design by investigating the rhetorical move structure of three tourist travel guides from Malaysia, Thailand and the Philippines. The selected data was based on the availability and applicability of online travel guide in those Asian countries' websites. To analyse the data, each of the travel guides were scrutinized carefully in order to identify the moves and their communicative purposes, based on Kathapalia's framework (1992). Atlas.ti software was used as tool for qualitative data analysis as it is a software that "can code a number of different media types, including text, images, videos, and audio." (Petrova, 2014, p 2).

The frequency count of the moves' occurrences were tabulated to identify the peripheral and central moves based on Howe's (1995) four grade system of strength level (most strong, quite strong, slightly strong, and not strong), and Choo's (1998) on distinguishing between the central and peripheral moves (the move that has frequency of $50 \%$ or above could be considered as a central). A pilot study was conducted with $\mathbf{8 8 \%}$ inter-rater reliability achieved with an English language specialist (Creswell, 2012) on selected data. The same analysis was subjected to the travel guides for Malaysia (MTG), Thailand (TTG) and Philippines (PTG). 


\section{RESULTS AND DISCUSSION}

Research question 1: What are the move structures, their strategies and communicative purposes in the selected travel guides?

The following moves identified in the three travel guides are shown in the table below:

Table 1 The analyzed moves in Malaysia, Thailand and the Philippines travel guides

\begin{tabular}{|c|c|c|c|}
\hline $\begin{array}{ll} & \text { Travel Guides } \\
\text { Moves } & \\
\end{array}$ & Malaysia & Thailand & The Philippines \\
\hline 1. Headline & $\checkmark$ & $\checkmark$ & $\checkmark$ \\
\hline 2. Appraising the country & $\checkmark$ & $\checkmark$ & $\checkmark$ \\
\hline 3. Justifying the country & $\checkmark$ & - & - \\
\hline 4. Targeting the Market & $\checkmark$ & $\checkmark$ & $\checkmark$ \\
\hline 5. Urging Actions & $\checkmark$ & - & - \\
\hline $\begin{array}{l}\text { 6. Important Contact Numbers and } \\
\text { Websites }\end{array}$ & $\checkmark$ & $\checkmark$ & $\checkmark$ \\
\hline 7. Endorsement & $\checkmark$ & - & $\checkmark$ \\
\hline 8. Extra Information & $\checkmark$ & $\checkmark$ & $\checkmark$ \\
\hline
\end{tabular}

Table 1 shows that five moves present in all the travel guides which are: Headline, Appraising the country, Extra Information, Important Contact Numbers and Websites, and Targeting the Market. The 'Endorsement' move is shared in both Malaysia's and Philippine's, while MTG has two moves unlike the others, which are 'Urging actions' move and 'Justifying the country' move.

\section{Move One: Headline}

The 'Headline' move is a very important move in all the travel guides as it hooks the attention of the reader and attracts him to read further. This is represented by a word, phrase or clause, with different font size and color to distinguish it from the body text. For example:
i. $\quad$ Selamat Datang... Welcome to Malaysia (MTG)
ii. Introduction to the Land of Smile (TTG)
iii. Baroque Churches of the Philippines (PTG) 
The 'Headline' move is realized through numerous strategies shown below:

Table 2 The strategies of headline move

\begin{tabular}{|c|c|c|c|}
\hline $\begin{array}{l}\text { Travel } \\
\text { Guide }\end{array}$ & MTG & TTG & PTG \\
\hline Strategies & $\begin{array}{l}\text { 1. Appraising the country } \\
\text { 2. Justifying the country }\end{array}$ & $\begin{array}{l}\text { 1. Appraising the country } \\
\text { 2. Justifying the country }\end{array}$ & $\begin{array}{ll}\text { 1. } & \text { Appraising the country } \\
\text { 2. } & \text { Justifying the country } \\
\text { 3. } & \text { The websites of attractions }\end{array}$ \\
\hline
\end{tabular}

\section{Move Two: Appraising the Country}

'Appraising the Country' relates to informative move that introduces the reader to the advertised country and its common attractions to convince and attract them to visit. The strategies are shown below:

Table 3 The strategies of appraising the country move

\begin{tabular}{|c|c|c|c|}
\hline $\begin{array}{l}\text { Travel } \\
\text { Guides }\end{array}$ & MTG & TTG & PTG \\
\hline Strategies & $\begin{array}{ll}\text { 1. } & \begin{array}{l}\text { Overview of the } \\
\text { country/destination }\end{array} \\
\text { 2. } & \begin{array}{l}\text { Describing specific places } \\
\text { in each region }\end{array} \\
\text { 3. Describing the shopping } \\
\text { 4. }\end{array}$ & $\begin{array}{l}\text { l. Identifying the country } \\
\text { by presenting the } \\
\text { following: } \\
\text { a. Culture } \\
\text { b. History } \\
\text { c. Climate } \\
\text { d. Religion } \\
\text { 2. Describing the country by } \\
\text { the following: } \\
\text { a. Overview the country } \\
\text { b. Describing the food } \\
\text { c. Describing service } \\
\text { d. Describing shopping } \\
\text { e. Health and aesthetic } \\
\text { f. Hell- being } \\
\text { fighlight in context }\end{array}$ & $\begin{array}{l}\text { 1. Appraising the } \\
\text { history of the } \\
\text { country } \\
\text { 2. Highlighting the } \\
\text { geological and } \\
\text { geographical } \\
\text { information } \\
\text { 3. Appraising the } \\
\text { attractions } \\
\text { (places to visit) } \\
\text { 4. Describing the } \\
\text { Country. } \\
\text { a. Introduction to } \\
\text { the country. } \\
\text { b. Climate } \\
\text { c. Food } \\
\text { d. Festivals and } \\
\text { Celebrations } \\
\text { e. Religion } \\
\text { f. Wild and natural } \\
\text { life } \\
\text { g. Language and } \\
\text { culture }\end{array}$ \\
\hline
\end{tabular}


The examples of the strategies above for each country are described below:

\section{Malaysia Travel Guide (MTG)}

\section{Overview of the Country/Destination}

The main and famous features of the country/place are put forth here namely the location, weather, and regions. For example: Situated in the midst of the Asia Pacific region, Malaysia enjoys a strategic location and a year-round tropical climate. With 13 states, three Federal Territories and a population that currently stands at more than 28 million, Malaysia combines the best of Asia and is well known for its diverse cultural landscape, which includes three of Asia's oldest civilisations - Malay, Chinese and Indian - and the unique ethnic communities of Sabah and Sarawak.

\section{Describing Specific Places in Each Region}

This part highlights factual and impressive places in each state that inform the reader to believe in its significance: Standing at 451.9m, the world-renowned Petronas Twin Towers is KLCC's centrepiece and one of the country's most famous icons. The Skybridge on the 41st floor doubles up as an excellent viewing platform of the city's skyline.

\section{Describing the Shopping}

The charms and advantages of shopping in each region of Malaysia is exemplified: $A$ shopping heaven in its own right, Kuala Lumpur caters to every taste, preference and budget. Swanky malls that double up as one-stop lifestyle centres such as Pavilion KL and Suria KLCC can be found around the city.

\section{Describing the Food}

In the MTG, there is one specific part for food in each region where the familiar main meal/s of each region in Malaysia is presented. This lures the reader to visit the country and try the popular dishes: Selangor has all kinds of culinary offerings, from international cuisine to local fare and from humble hawker stalls to posh five-star restaurants. When it comes to food, the most popular delicacy in this state is perhaps the Satay Kajang.

\section{Listing More Destinations to be Visited in Each Region}

Listing more destination raises the likelihood of the destination to be visited. Examples include valuable attractions that could be visited: Shah Alam Lake Garden, or Islamic Arts Garden Complex 


\section{Housing Information}

Another example to appraise the country is by describing the variety of accommodation available in Malaysia or anyone. For example, Whether it is five-star or budget, you can find all types of accommodation in Selangor. Most of these accommodation are situated near shopping malls and within town centres, offering both comfort and convenience.

\section{Talking about Special Events and Activities}

Appraising Malaysia is also done by pinpointing Malaysia's numerous festivals, events and activities: Putrajaya is the venue of many exciting and colourful events. The annual Putrajaya FLORIA is a much awaited event for both locals and foreign visitors, held every year at Dataran Putra.

\section{Highlighting the Country/Destination in Context}

This new strategy highlights significant details and information about specific attractions vis a vis the image of the attraction: Petronas Twin Towers is currently the world's tallest twin structure and fifth tallest skyscraper. The skybridge that links the two towers symbolises a gateway to the future.

\section{Thailand Travel Guide (TTG)}

\section{Identifying the Country}

This strategy communicates the pleasing but unique characteristics of Thailand in terms of its culture, history, climate and people. For example, Culture - People and culture are considered as features of a country where they play major roles to distinguish one country from another. Besides, the harmony between different cultures and races in a country represents the freedom and the democracy there. The previous two examples signify the pure southeast culture in Thailand and the harmony between the variety of races, which attract the reader's attentions to visit the country and witness the culture harmonies there.

\section{Describing the Country}

Describing the country draws out the beauty and charms of the country in words. It is designed to appeal to those who are interested thus enticing them to visit the country. Examples include:

\subsection{Overview of the Country}

This strategy helps the reader obtain a general impression of the destination: Central Plains: Twentyfour provinces make up central Thailand with Bangkok as its centre. The rain-fed network of rivers and 
canals makes this the most fertile part of Thailand, supporting vast fields of rice, sugar cane and a variety of fruit.

\subsection{Describing the Food}

TTG presents the nature of local Thai food which may appeal to the reader to attempt: Thai cuisine is unique, blending a multitude of spices and ingredients that make each dish a special joy. It is common to be served dishes that include hot, sour, sweet and salty flavours at one meal. A typical Thai meal will include soup, salad, fish, rice, vegetables, and sometimes a meat dish, either pork, chicken or beef.

\subsection{Describing Service}

Countries could be classified according to the services and facilities that they offer for locals and tourists, as well. TTG presents two important services for tourists which are medical and communication services: Thailand's mail service is both reliable and efficient, Major hotels provide basic postal services on their premises. Other services are found in 'Extra information' move.

\subsection{Describing Shopping}

The TTG presents the name of famous malls and the unique goods that are only available there: Fabric is the best all-round buy in Thailand, with Thai silk being considered the best in the world.

\subsection{Health and Aesthetic Well-Being}

Thailand is famous for its spas and massages which are prominently highlighted: Thailand is fast becoming the "health holiday" capital of the world. Some of the world's finest spas are found in Thailand.

\subsection{Highlight in Context}

Important attractions are conspicuously highlighted using different color, font size and location in the text. Often stated next to the image of the attraction, the highlighted texts are extracted from the travel guide body's texts to poignantly remind the reader with significant tips: There are also many mega-malls like Siam Paragon, the biggest mall in Southeast Asia, the extraordinary Central World Plaza, the Platinum Fashion Mali and the Emporium which is famous for fashion.

\section{Your Guide to the Philippines (PTG)}

\section{Appraising the History of the Country}

This strategy is used to present Philippines' historical existence with emphasis on the cultural or ancient tradition and heritage rooted in the country: 
The Metal Ages (2,000 B.C-1,000 A.D) made way for the ancient bronze tools for the ancient man as well as the start of Philippine Maritime History. A total of nine prehistoric boats were found in Butuan, Agusan del Norte, the earliest of which dated to 320 A.D.

\section{Highlighting the Geological and Geographical Information}

The unique location and construction of the country are exemplified by this strategy. Both present scientific information, at times quoting some scholars' words, to support and justify the country's charms to attract readers. For example: The Philippine archipelago spans roughly $1900 \mathrm{~km}$ from north to south and around $1,110 \mathrm{~km}$ from east to west. The three main island groups, Luzon, Visayas and Mindanao, divide the country into north, central and southern regions respectively.

\section{Appraising the Attractions (Places to Visit)}

This strategy focuses on the famous attractions in main cities of the Philippines, by explaining the feature of the attraction. For example:

The National Museum of the Philippines is the premier repository and custodian of the country's heritage. The National Museum Complex consists of the National Art Gallery, the Museum of the Filipino People, the Planetarium and soon, the Museum of Natural History.

\section{Describing the Country}

This strategy usually presents an introduction to the country, describes climate and food, and talks about festivals, religion, language and culture. For instance,

\subsection{Introduction to the Country}

It introduces the Philippines to the reader by including its official name, location, parts of the capital city: Officially known as Republic of the Philippines, the Philippine Archipelago is a sovereign country located in Southeast Asia. The country lies north of the equator and is part of the Pacific Ring of Fire.

\subsection{Climate}

This strategy informs readers on the country's climate and how it usually is during the year: Hot and dry climate is expected during March until May. The rainy season begins in June until October with July to September characterized by tropical cyclones. 


\subsection{Food}

Food is also described for the sake of the traveler which leaves a good impression on the country's delicacies: Philippine cuisine is as diverse as the different cultural groups that make up the Filipino people. It is flavored by a rich variety of herbs and spices found all over the islands.

\subsection{Festivals and Celebrations}

Tourism is also about knowing the cultural festivals and celebrations of the country which can entice the traveler or reader to join in the fun

Major fiestas that draw the most number of tourists are the Sinulog Festivalb(Cebu), Dinagyang Festival (IloIlo) and Ati-atihan (Aklan), all in honor of the child Jesus (Sto. Niño). The Panagbenga Festival (Baguio City) and Pahiyas Festival (Quezon) celebrates abundant harvest for the year.

\subsection{Religion}

Religious practices of the nation are also announced in the travel guide which helps the reader to overcome intercultural differences, if any:

The Philippines is a predominantly Christian nation making it the only one in Southeast Asia. In Mindanao, a large number of Muslim Filipinos keep the Islam traditions and faith alive. Buddhism is practiced mostly by Filipinos with Chinese descent. Although in a minority, Hinduism, Protestantism, Taoism, Confucianism and other faiths are also practiced in the country.

\subsection{Wild and Natural Life}

Examples of Philippines' diverse natural and wild life are mentioned as part of appraising the country's attractions: It is home to 70-80\% of the world's biodiversity. It hosts 52, 177 described species, half of which are endemic or is found nowhere else in the world.

\subsection{Language and Culture}

The Philippines' rich language and culture are also featured which promote intercultural understanding and awareness:

Filipino is the national language of the Philippines and, along with English, one of two official languages. There are more than 100 native languages in the different parts of the archipelago most of which belong to the Austronesian language family. 


\section{Move Three: Justifying the Country}

This move details specific and concrete reasons for the reader to travel to the destination. and why it is different from others. It appears only in MTG with three strategies exemplified below:

Table 4 The strategies of justifying the country move

\begin{tabular}{|c|c|c|c|}
\hline Travel guides & MTG & TTG & PTG \\
\hline Strategies & $\begin{array}{l}\text { 1. Highlighting the uniqueness of the } \\
\text { country, } \\
\text { 2. Indicating special events, festivals } \\
\text { and actions to make the country } \\
\text { chosen as the best destination for } \\
\text { vacation, and } \\
\text { 3. Presenting reasons that justify the } \\
\text { uniqueness of the country. }\end{array}$ & - & - \\
\hline
\end{tabular}

\section{Highlighting the Uniqueness of the Country}

This strategy emphasizes rational reasons by positing Malaysia as a desired tourist destination. Malaysia is one of the region's top destinations for sun, sea and sand getaways.

\section{Indicating Special Events, Festivals and Actions in the Country}

Advertising special actions, events or festivals is important to attract people to visit the country and provide more justification for them to join the events. For example: The country is also known for its colorful festivals and exciting events held throughout the year such as Formula One Grand Prix, Langkawi International Maritime and Aerospace Exhibition (LIMA), the 1Malaysia Year End Sale (M-YES), the 1Malaysia GP Sale and the 1 Malaysia Mega Sale Carnival.

\section{Listing Reasons to Choose the Country as the Next Destination for Holiday}

This strategy has its power over the reader's decision where it provides him with numerous reasons to visit the country/destination: A myriad of Asian cultures - and more - all in one place; ii. Political stability, racial harmony and genuinely warm people

\section{Move Four: Targeting the Market}

This move is prevalent in all the travel guides which is in line with previous studies by Zanariah (2003), Choo (1998), and Howe (1995) based on Kathpalia's framework (1992) whereby the same communicative purposes and aims are achieved, with differences in the strategies employed. The 
variety of strategies in this move could be subjected to the nature of the advertised country (Table 6). Travel guides predominantly attract and lure readers to visit the country advertised, but the nature and character of the country could affect the strategies that the writer uses to achieve his aims. While the MTG mainly targets people who are looking for entertainment, it could be seen that TTG aims tourists who favor history and religion. Alternatively, the PTG seems to focus on the geographical features of the country to attract those who are interested in such subjects.

Table 5 The strategies of targeting the market move

\begin{tabular}{|c|c|c|c|}
\hline $\begin{array}{l}\text { Travel } \\
\text { Guides }\end{array}$ & MTG & TTG & PTG \\
\hline Strategies & $\begin{array}{l}\text { 1. Targeting the market } \\
\text { according to Purpose of } \\
\text { Travel } \\
\text { 2. Personalising target market } \\
\text { 3. Highlighting specific } \\
\text { activities and cuisine. } \\
\text { 4. Naming the market directly }\end{array}$ & $\begin{array}{l}\text { 1. } \\
\text { inteferring to their } \\
\text { favorite activities }\end{array}$ & $\begin{array}{l}\text { 1. Targeting the } \\
\text { market } \\
\text { indirectly }\end{array}$ \\
\hline
\end{tabular}

The 'Targeting the market' move is recognized in different parts of the MTG. It uses different strategies (sub-move) to identify and address the audience directly and indirectly in order to gain attention, persuade and attract them to visit the country:

\section{Targeting the Market According to Purpose of Travel}

This strategy presupposes the various motivations behind visiting the country. It impresses upon the reader on the kinds of entertainment and environment suited for various travel purposes: Whatever the reason for your visit - a romantic escapade, a fun-filled family holiday, an all-out shopping spree or a quiet retreat at the heart of nature - Malaysia has it all.

\section{Highlighting Specific Activities and Cuisine}

This strategy sets the idea of 'One is known by his deeds' where it uses commonplace activities and food of the country to entice readers or travelers: Selangor has all kinds of culinary offerings, from international cuisine to local fare and from humble hawker stalls to posh five-star restaurants.

\section{Naming the Market Directly}

The target market is clearly and directly mentioned in the body of the advertisement under this submove. For example, Most eateries serve halal food, so Muslims would feel right at home dining in this cosmopolitan city. 


\section{Personalizing Target Market}

A personalized meaning to the reader is established with the usage 'you' and 'your' pronouns. This engages the reader's mental state where he feels more in tuned with the persuasive message given: Kuala Lumpur plays host to a number of international, sporting, cultural and recreational events throughout the year that are sure to set your pulse racing.

In TTG, Targeting the Market move is based on directing specific groups of readers by referring to their interests and favorite activities: For travelers, Thailand is the only gateway in which to experience the special life of Southeast Asia. Due to the fact that the country has never been colonised, the Thai individuality blooms and remains vibrant.

For the Philippines travel guide, this move aims at specific groups directly or indirectly to read on about the country's attractions and activities. Seven examples of targeting the market were found according to Kathpalia's framework (1992); indirectly targeting and appealing to them to visit the attractions: The Museo Pambata is a children's interactive museum, the first of its kind in the Philippines. It features hands-on exhibits that encourage children to explore and discover various concepts while they play.

\section{Move Five: Urging Action}

This move encourages the reader to visit the places previously described using distinctive expressions of recommendation or encouragement. For example:

But do not just take our word for it. Come and discover the many wonders of Malaysia and peel the many layers of this fascinating country. Be prepared to be amazed, because there is just so much more to Malaysia than meets the eye.

Table 6 The strategies of Urging action move

\begin{tabular}{|l|l|l|l|}
\hline Travel guides & MTG & TTG & PTG \\
\hline Strategies & $\begin{array}{l}\text { 1. Telling the reader to } \\
\text { do so directly }\end{array}$ & - & - \\
\hline
\end{tabular}

It seems that the author of MTG has a better background about the advertisement's writing than the those who are in charge with Thailand and the Philippines Travel Guides. Moreover, the nature of MTG may require this move due to the focus on the entertainment topics, while the other two travel guides focus on geographical, historical, and religious topics which seem not to require urging actions. 


\section{Move Six: Important Contact Numbers and Websites}

This new move not present in Kathpalia's framework (1992) provides important contact numbers or required information for travel. This unique move must ensure reliable information given to convince the reader to have a sense of security or surety. For instance, in the MTG, important contact numbers are given: Immigration and Tourism Center, Tourism Malaysia 130088 5050, +603 88918000 , www.tourismmalaysia.gov.my_(See Table 8).

Table 7 The strategies of important contact numbers and websites move

\begin{tabular}{|c|c|c|c|}
\hline Travel guides & MTG & TTG & PTG \\
\hline Strategies & $\begin{array}{cl}\text { 1. } & \begin{array}{l}\text { Immigration and } \\
\text { tourism center }\end{array} \\
2 . & \text { Emergencies } \\
3 . & \text { Airlines } \\
4 . & \text { Transport } \\
5 . & \text { Credit card } \\
6 . & \text { Others }\end{array}$ & $\begin{array}{ll}\text { 1. } & \text { General } \\
\text { information about } \\
\text { the country } \\
\text { 2. Visa information } \\
\text { 3. Transport }\end{array}$ & $\begin{array}{ll}1 . & \text { Travelling } \\
\text { information and } \\
\text { agencies }\end{array}$ \\
\hline
\end{tabular}

\section{Move Seven: Endorsement}

This move assumes the same role and communicative purposes of giving support and acknowledgment on the attractions. It seems that Thailand travel guides focuses more on 'appraising the country' than 'endorsement' of the country. This is explained by the numerous historical or heritage sites in Thailand needed to be appraised rather than endorsed. It may also be that this is not a requirement to be placed in the guide which can be purely subjective to the writer. Table 9 shows the move and strategies for the Malaysian and the Philippines travel guides.

Table 8 The strategies of endorsement move

\begin{tabular}{|l|l|l|l|}
\hline Travel guide & MTG & TTG & PTG \\
\hline Strategies & $\begin{array}{l}\text { Stating the given } \\
\text { rewards and world } \\
\text { ranking of the advertised } \\
\text { destination }\end{array}$ & - & $\begin{array}{l}\text { Use of the UNESCO } \\
\text { Certifications to } \\
\text { Highlight the ancient } \\
\text { places in the } \\
\text { country, and use the } \\
\text { national and world } \\
\text { record to highlight } \\
\text { others }\end{array}$ \\
\hline
\end{tabular}


As an example:

The Newport Performing Arts Theater holds the distinction of being Broadway World Philippines' Best Theatrical Venue for 2011. (PTG)

\section{Move Eight: Extra Information}

This complex move has many strategies employed to achieve its purpose. Extra information on facilities, culture and language lend more reasons to persuade the reader. This move, which was not mentioned in Kathpalia's framework (1992) or other genre analysis studies, indicates that travel guides are more extensive than brochures in terms of the information presented. Travel guides present the advertised country holistically with all its features and characteristics, whereas brochures usually focus only on one attraction or one part of the country. This requires travel guides to be more powerfully purposeful, informative and explanatory in order to provide the best image of the country for potential tourists. Table 10 presents the different strategies used for this move.

Table 9 The strategies of extra information move

\begin{tabular}{|c|c|c|c|}
\hline Travel Guide & MTG & TTG & PTG \\
\hline Strategies & 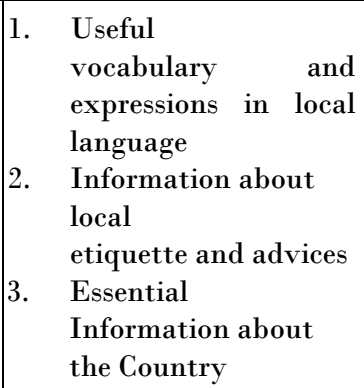 & $\begin{array}{l}\text { 1. } \begin{array}{l}\text { Extra information } \\
\text { about } \\
\text { country }\end{array} \\
\text { 2. Transportation } \\
\text { 3. Etiquette } \\
\text { 4. Services } \\
\text { 5. General } \\
\\
\text { regulation }\end{array}$ & $\begin{array}{ll}\text { 1. } & \text { Rules and } \\
& \text { Regulations } \\
\text { 2. } & \text { Advices } \\
\text { 3. } & \text { Currency } \\
& \text { Description } \\
\text { 4. } & \text { Transport } \\
\text { 5. } & \text { Visa } \\
& \text { Information }\end{array}$ \\
\hline
\end{tabular}

Examples for the first strategy in MTG include Welcome/Selamat datang or Good morning/Selamat pagi, where as information on local etiquette and advice are given for the traveler to avoid misunderstanding or culture clash, for example, While visiting a homestay village, please be respectful of local customs and traditions.

The third strategy states the Essential Information about the Country that has to do with the way the country is governed:

Malaysia practices parliamentary democracy and constitutional monarchy. The Head of State is the Yang di-Pertuan Agong and the Head of Government is the Prime Minister. (MTG) 
Extra Information move in TTG, is a new move not mentioned in Kathpalia's framework. It is based on presenting extra information that facilitate visitors. Some of these strategies could stand as a move by itself or related to one of Kathpalia's moves if they contain more detailed information and particular strategies.

\section{Extra Information about the Country}

This strategy represents essential details about the country to educate the reader about time, money, language, media, clothes and others, for example:

The government of Thailand is a Constitutional Monarchy inspired by the British democratic model. National polls elect the 500-member House of Representatives and the Prime Minister every four years, and the 200- member Senate every six years.

The second strategy under Extra Information for TTG is Transportation, which describes Thailand's travelling methods to the reader, e.g. Flying in Thailand is both inexpensive and convenient. Several air carriers such as Thai Airways international, Bangkok Airways, FB Air, Phuket Air.

Visiting new countries means to be introduced to new cultures and etiquette. The main idea of this next strategy in TTG is to introduce the reader to the unique culture and etiquette of the Thais, ie. table or eating etiquettes and tipping strategy to help familiarization of local norms. For instance, It is customary to tip porters and hotel personnel who give good service. A 10-15\% tip is customary in most high-end restaurants and hotels, particularly where service charges are waived.

Under 'Services' strategy, most of the examples have to do with catering to the visitors' traveling needs, e.g. Instant development can be done within one hour at most places. Popular brands of film (Kodak, Kontca, Fuji) are available nationwide at reasonable prices. Extra information for TTG also include some 'General Regulation' to visit Thailand like requirements of visa, passport validity, and health state reports, e.g. All visitors are required to possess a valid passport and to obtain appropriate visas before entering Thailand.

As for the PTG, the 'Extra Information' move is exemplified in terms of five strategies namely 'Rules and Regulations' which can be stringent but send a message of enforcement.

Upon arrival, visitors may bring in: a. duty-free personal belongings, b. two cartons of cigarettes or two tins of pipe tobacco, $c$. up to one liter of alcohol

'Advices' is the next strategy that reminds the reader on safety aspects which could guide him/her from any danger or risks in travelling. Such considerations inform tourists in the best possible way in order to enjoy their stay in the country. For instance, It is advisable to have your money exchanged before leaving an international airport. Exchanging money anywhere else is illegal and the laws are strictly enforced.

Currency Description is also provided as a strategy to inform the reader ahead on the currency in the Philippines, e,g, The country's currency is the Philippine Peso (PHP). A peso is divided into 100 centavos (officially centimo). Current coins are of 1, 5, 10, and 25 centavos and 1 and 5 pesos. In addition, 
the fourth strategy in the PTG has to do with information on transportation like air, sea and land fares to give options to the reader to choose local transportation, e.g. Flying with the country's local airlines makes travelling around the country's 1707 islands faster and much more comfortable. Flight schedules, destinations and air fares information are listed in the following websites.

The final strategy under the Extra Information move is 'Visa Information' which helps the reader to be familiar with the countries that do not require a tourist visa. Moreover, it provides information on visa validity and special cases. The following example defines this strategy: Nationals from countries listed below who are traveling to the Philippines for business and tourism purposes are allowed to enter the Philippines without visas for a stay not exceeding thirty (30) days, provided they hold valid tickets for their return journey to port of origin or next port of destination and their passports valid for a period of at least six (6) months beyond the contemplated period of stay (PTG)

Research Question 2: What are the prevalent move/s in the selected travel guides?

To identify the prevalent move/s, the occurrences and frequencies of all moves in the three travel guides were collected and categorized in the following table to determine the peripheral and central move/s.

Table 10 Moves and their occurrences and percentages

\begin{tabular}{|c|c|c|c|c|c|c|}
\hline \multirow{2}{*}{$\begin{array}{|rr|} & \text { Travel } \\
& \text { Guide } \\
\text { Moves } & \\
\end{array}$} & \multicolumn{2}{|l|}{ MTG } & \multicolumn{2}{|l|}{ TTG } & \multicolumn{2}{|l|}{ PTG } \\
\hline & occurrences & $\%$ & occurrences & $\%$ & occurrences & $\%$ \\
\hline 1. Headline & 230 & 37.76 & 144 & 41.14 & 106 & 45.29 \\
\hline $\begin{array}{l}\text { 2. Appraising the } \\
\text { country }\end{array}$ & 232 & 38.09 & 120 & 34.28 & 92 & 39.31 \\
\hline $\begin{array}{l}\text { 3. Justifying the } \\
\text { country }\end{array}$ & 34 & 5.58 & - & - & - & - \\
\hline $\begin{array}{l}\text { 4. Targeting the } \\
\text { Market }\end{array}$ & 44 & 7.22 & 7 & 2 & 7 & 2.99 \\
\hline 5. Urging Actions & 4 & 0.65 & - & - & - & - \\
\hline $\begin{array}{ll}\text { 6. } & \text { Important } \\
\text { Contact } \\
\text { Numbers and } \\
\text { Websites } \\
\end{array}$ & 17 & 2.79 & 15 & 4.28 & 7 & 2.99 \\
\hline 7. Endorsement & 21 & 3.44 & - & - & 4 & 1.70 \\
\hline $\begin{array}{ll}\text { 8. } & \text { Extra } \\
& \text { Information } \\
\end{array}$ & 27 & 4.43 & 64 & 18.28 & 18 & 7.69 \\
\hline TOTAL & 609 & 100 & 350 & 100 & 234 & 100 \\
\hline
\end{tabular}


Table 10 shows Headline and Appraising the Country moves with the highest occurrences and percentages. This can be considered as the central moves according to Howe's (1995) four grade system of strength level. On the other hand, Choo's format (1998) on distinguishing between the central and peripheral moves may be irrelevant as the highest percentage in all the analyzed moves is $45.29 \%$ for PTG. This indicates that the central moves in the travel guide of Malaysia, Thailand and Philippine are Headline and Appraising the Country; while the peripheral moves are moves which have occurrences in all the three travel guides, namely, Targeting the Market, Important Contact Numbers and Websites, and Extra Information.

Research Question 3: To what extent are the move patterns different in the three travel guides?

The results of the analysis have shown that not all the travel guides have the same number of move patterns and are different from each other in terms of their purposes. While Malaysia travel guide contain eight moves, the Thai guide shows only five moves and the Philippines, with six moves. This result confirms flexibility in moves which stated by Bhatia (1993) and Zanariah (2003).

\section{CONCLUSION}

The findings correspond with studies by Kathpalia (1992), Zanariah (2003), Choo (1998), and Howe (1995), who found the important role of Headlines in attracting and capturing the reader's attention through its compelling and persuasive appeal. Two dominant moves exist in the travel guides with the highest occurrences, ie. Headline and Appraising the Country, while, the variety of peripheral moves found depends on the nature of country, perception and aims of the writer. The diversity of moves assures the flexibility of peripheral moves in travel guides. The findings of this study offers a framework for module development in ESP training focusing on tourism and marketing writing skills. The findings could also be used as a guideline to produce travel guides in countries that do not have such promotional documents. The diversity of moves in the three analyzed samples confirms the flexibility of promotional genre stated by Bhatia (1993). This study assures that there is no fixed format for tourist promotional genre, and gives freedom to the writer of the advertisements to use his perceptions on the nature of the advertised country to achieve his communicative purposes.

\section{REFERENCES}

Amerrudin Abd Manan, Farideh Moradi Goloshejerdi. 2015. Analyzing Tourism Discourse in the Context of Iranian Promotional Media. LSP International Journal. 2(1): 75-82.

Berger, A. A. 2004. Deconstructing Travel: Cultural Perspectives on Tourism. Rowman Altamira.

Bhatia, V. 1993. Analysing Genre: Language Use in Professional Settings. 1st ed. London u.a.: Routledge.

Bhatia, Vijay.K. 2004. Worlds of Written Discourse. New York: Continuum 
Bobanovic, M. K., \& Grzinic, J. 2011. The Importance of English Language Skills in the Tourism Sector: A Comparative Study of Students/Employees Perceptions in Croatia. AlmatourismJournal of Tourism, Culture and Territorial Development. 2(4): 10-23.

Cheng, W., \& Suen, A. O. Y. 2014. Multimodal Analysis of Hotel Homepages: A Comparison of Hotel Websites Across Different Star Categories. The Asian ESP Journal. 10(Special Issue), 5-33.

Choo, H. L. 1998. A Genre-based Analysis of Property Advertisements in a Local Newspaper. Unpublished MA Dissertation, Faculty of Languages and Linguistics, University of Malaya.

Creswell, J. 2012. Educational Research: Planning, Conducting, and Evaluating Quantitative. 4th ed. Lincoln: Pearson.

Dann, G. M. 1996. The Language of Tourism: A Sociolinguistic Perspective. Cab International.

Dudley-Evans, T. 1994. Genre Analysis: An Approach to Text Analysis for ESP. Advances in Written Text Analysis. 219: 228.

Henry, A., \& Roseberry, R. L. 2001. A Narrow-angled Corpus Analysis of Moves and Strategies of the Genre: 'Letter of Application.' English for Specific Purposes. 20(2): 153-167.

Henry, A., \& Roseberry, R. L. 1996. A Corpus-based Investigation of the Language and Linguistic Patterns of One Genre and the Implications for Language Teaching. Research in the Teaching of English. 30(4): 472-489. http://doi.org/10.2307/40171553.

Holovach, T. 2016. The English Travel Guide as a Genre of Intercultural Communication. International Scientific Refereed Online Journal. (19): 10-15.

Howe, Y. S. 1995. A Genre-based Analysis of Car Advertisements in a Local Newspaper. Unpublished Thesis, National University of Singapore.

Huang, S. 2015. A Genre-based Analysis of Brief Tourist Information Texts. International Social

Science, Education, Language, Management and Business Conference (JISEM 2015). 191-202.

Huyen, N. T. T., \& Nga, K. T. T. 2003. Learning Vocabulary through Games. Asian EFL Journal. 5(4): 90-105.

Iborra, S. A., \& Garrido, F. R. M. 2001. The Genre of Tourist Leaflets. PASAA. 32: 71-81.

Jun, Z. 2008. A Comprehensive Review of Studies on Second Language Writing. HKBU Papers in Applied Language Studies. 12: 89-123.

Kathpalia, S. S. 1992. A Genre Analysis of Promotional Texts. National University of Singapore.

Luo, J., \& Huang, T. 2015. Genre-based Analysis of American Tourism Brochure. Open Journal of Social Sciences. 3(09): 200.

Malaysia Travel Guide. 2015. http://www.tourismthailand.org/Multimedia/ebrochuresearch?destination_id=\&cat_id=\&lang_id=\&keyword=travel+guide.

Osman, H. 2013. Pedagogic Genre Analysis: A Module for Copy-Writing. English for Specific Purposes World.

ÖZTÜRK, B. 2014. Türkçe Bir Turizm Broşür Çözümlemesi Örneği: Kemer. The Journal of Academic Social Sciences. 2(2): 321-321. doi:10.16992/asos.98.

Petrova, V. 2014. Intro to Atlas. ti : Qualitative Data Analysis Software, (June). Retrieved from http://julius.csscr.washington.edu/pdf/atlasti.pdf.

Salehi, H., \& Farahbakhsh, M. 2014. Tourism Advertisement Management and Effective Tools in 
Tourism Industry. International Journal of Geography and Geology. 3(10): 124.

Sirikhan, S., \& Prapphal, K. 2011. Assessing Pragmatic Ability of Thai Hotel Management and Tourism Students in the Context of Hotel Front Office. Asian EFL Journal Professional Teaching Articles. 53(July): 72-94. https://doi.org/10.1088/1674-1056/23/4/046105.

Swales, J. 1990. Genre Analysis: English in Academic and Research Settings. Cambridge University Press.

TravelGuide Amazing Thailand. 2007. http://www.tourismthailand.org/Multimedia/ebrochuresearch?destination_id=\&cat_id=\&lang_id=\&keyword=travel+guide.

Your Guide to the Philippines. 2014. http://www.inal5.upd.edu.ph/files/Guidebook\%20v2.pdf.

Zanariah Abd. Shukor. 2003. A Genre-based Analysis of Print Advertisements for Hospitality and Tourism. Unpublished Thesis. University of Malaya. 